\title{
ヨウ素酸ナトリウムの熱分解
}

\section{The Thermal Decomposition of Sodim Iodate}

1 緒言

既報》に示した亜塩素酸ナトリウムの新製法に関し て，ヨウ素イオンを含むカセイソーダ水溶液と二酸化塩 素の反応の結果生成するヨウ素酸ナトリウムからヨウ化 物を能率よく回収することは重要な問題である。

ヨウ索酸塭付対する熱の作用は，塩素酸塩や臭素酸㙁 に対すると同じように，その熱分解反応に 2 種類が考元 られる。すなわち酸素発生反応と酸素およびョウ素発生 反応いずれかがおうりうるが，M. Berthelot ${ }^{2}$ は酸素 の放出のみでヨウ化物が生成すること，また C.F. Rammelsberg $^{3)}$ 法過ヨウ素酸塩の生成は認められず同し くヨウ化物が生成すると報告している。ててに対して E.H. Cook $^{4}$ (は少量のヨウ素が発生するこ之を談めた。 てれらのヨウ素酸㙏はすべてカリウム塩についての報文 でナトリウム塩に関する報告は見当たらない，ててにヨ ウ素酸ナトりウムの熱分解反応について検討を行なっ た。

\section{2 実験方法および装置}

試験に供したヨウ素酸ナトリウムはつぎのようにして 調製した。カセイソーダ水溶液にヨウ素を溶解し，二酸 化塩素を導入して生成するョウ素酸塩を口別・水洗し， 数回水汃再結晶を行なったのち，105드て乾燥し た.純分は $90.2 \%$ で他は結晶水である。

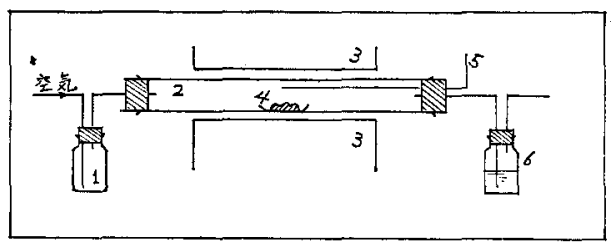

図 1 加熱分解試験装置

分析方法は既報1に記載の方法に準じて行なった。加 熱分解試駼装置を図 1 亿示す。一定量の武料を磁製ボー 卜（4）にとり石英ガラス管（2）内にそう入し，電気炉 （3）中にて所定の温度・時間加熱した。 なお少量の空気 をシリカゲル充てんの乾燥びん（1）を通して反応管内に 導入して，発生ガスを希カセイソーダ水浴液をいれた捕 集びん（6）中に四収させた。
渡 辺 憲 一*, 清 水 昭 一**

Kenichi Watanabe, Shoichi Shimizu

\section{3 実験結果亡考察}

試料約 $1 \mathrm{~g}$ をとり, $300^{\circ} \mathrm{C}, 400^{\circ} \mathrm{C}, 500^{\circ} \mathrm{C}, 600^{\circ} \mathrm{C}, 650$ ${ }^{\circ} \mathrm{C}$ にそれぞれ加熱した電気焒中にそう入して熱分解を 行なった。

その分解率およびヨウ素損失を測定した結果を図 2 ， 图 3 亿示玄。乙机によると $300^{\circ} \mathrm{C} ， 5$ 時間では，全く分 解は見られず， $650^{\circ} \mathrm{C}$ で站約 30 分で完全に分解した。

ての場合の ヨウ素損失は $1.5 \%$ であった. $500^{\circ} \mathrm{C}$ 以 上で酸蒵の放出をはじめ，加熱時間にほぼ比例してョウ

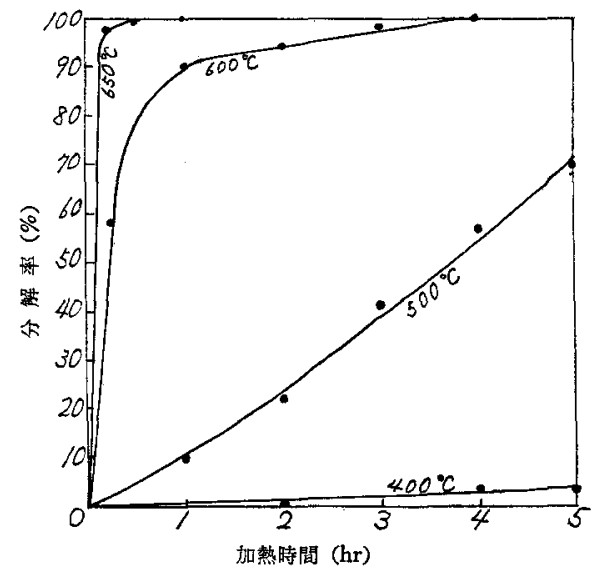

図 $2 \quad \mathrm{NaIO}_{\mathbf{3}}$ の加熱分解率

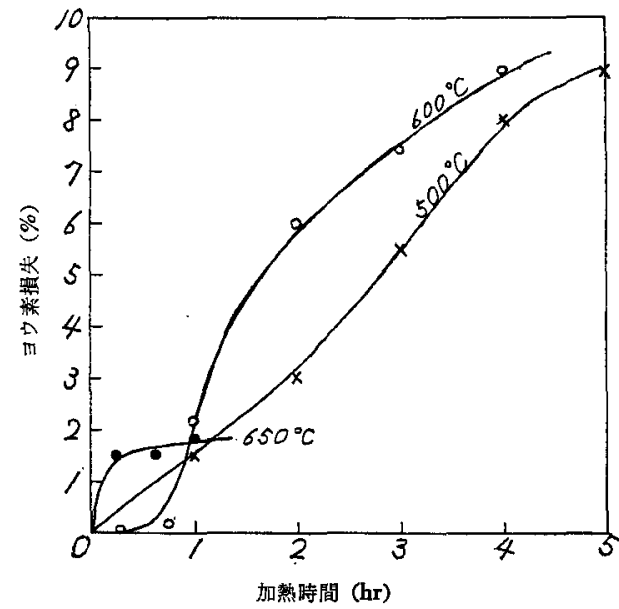

因 $3 \mathrm{NaIO}_{8}$ ○熱分解儿よるヨウ素損失 
表 $1 \mathrm{NaIO}_{3}$ の熱分解率と回収率 $\left(650^{\circ} \mathrm{C}\right)$

\begin{tabular}{|c|c|c|c|c|c|c|c|}
\hline \multirow{2}{*}{$\begin{array}{l}\text { 奉 } \\
\text { 騍 } \\
\text { 䎹 }\end{array}$} & \multicolumn{4}{|c|}{ 回收 $\exists$ ウ索* } & 生成物割合 & \multirow{2}{*}{$\begin{array}{c}\text { 分解率 } \\
(\%)\end{array}$} & \multirow{2}{*}{$\begin{array}{c}\text { 回収率 } \\
(\%)\end{array}$} \\
\hline & $\stackrel{I_{2}}{(g)}$ & $\begin{array}{l}\mathrm{NaI} \\
(\mathbf{g})\end{array}$ & $\underset{(\mathrm{g})}{\mathrm{NaIO}_{3}}$ & 合 計 & $\mathrm{I}_{2}: \underset{(\mathrm{mol} \%)}{\mathrm{NaI}}: \mathrm{NaIO}_{3}$ & & \\
\hline 1 & 0.190 & 8.766 & 0.104 & 9.06 & $2.1: 96.8: 1.1$ & 98.7 & 100 \\
\hline 2 & 0.140 & 8.750 & 0.090 & 8.98 & $1.5: 97.4: 1.1$ & 98.9 & 99.2 \\
\hline 3 & 0.119 & 8.941 & 0 & 9.06 & $1.3: 98.7: 0$ & 100 & 100 \\
\hline 4 & 0.162 & 8.898 & 0 & 9.06 & $1.7: 98.3: 0$ & 100 & 100 \\
\hline
\end{tabular}

注 * $\mathrm{NaIO}_{3}$ 換算にて示与.

素損失は増加する。これはての温度で酸素のほかに，ヨ ウ素ガスの発生しているてとを示している．しかしての ヨウ秦はカセイソーダに吸収させて回収されるので真の 損失にはならない，さらに $650^{\circ} \mathrm{C} に て$ 約 30 分間同样に して加熱・溶融し, 分解生成物について行なった分析結 果を表 1 に示す. 試料はすべて $10.05 \mathrm{~g}$ を採取した.

てれ化よると 1 2\%のヨウ秦発生は避けられないが 回収率から見ればこの場合は問題にならない.ヨウ素酸 ナトリウムに少量の木炭を添加して加熱還元する時は分 解温度 $350^{\circ} \mathrm{C}$ にて無添加の場合の $650^{\circ} \mathrm{C}$ と同樣であ。 た. $\mathrm{NaIO}_{3}: \mathrm{C}=1: 1$ モル比で完全にヨウ化物化還元さ れて，ヨウ续の発生は同程度であった。この場合還元物 はカセイソーダに溶解してロ過すれば残存炭素は回收使 用するととができる。との熱分解過程について予想され る反応は

$$
\mathrm{NaIO}_{3}(s)=\mathrm{NaI}(s)+3 / 2 \mathrm{O}_{2}
$$

いま Nernst の熱定理式より誘導した近似式を用いて， (1) 式の平衡定数と温度の関係式を求めるとつぎのよう になる。

$\log K=-\Delta F^{\circ} / 2.303 R T=-\Delta H / 2.303 R T$ $+\sum n \cdot 3.5 \ln T / 2.303 R T-\Sigma n_{i} / 2.303 R$ $=Q / 4.574 T+\sum n \times 1.75 \log T+\sum n I$

ただし $Q$ は反応熱 (cal)， $n$ は反応系中の 気相成分 のモル数の差， $I$ は暫定化学定数を示す. 以下熱力学数 值は電気化学便覧 (丸善)によった。

$\mathrm{NaI}(s)$ の生成熱 $\Delta H_{1}=-69,280 \mathrm{cal} / \mathrm{mol}$

$\mathrm{NaIO}_{3}(s)$ の生成熱 $\Delta H_{2}=\Delta H_{3}+\Delta H_{4}-\Delta H_{5}+\Delta H_{6}$

こと

$\Delta H_{3}=\mathrm{KIO}_{3}(l)$ の生成熱 $=-115,180 \mathrm{cal} / \mathrm{mol}$

$\Delta H_{4}=\mathrm{NaCl}(l)$ の生成熱 $=-97,324 \mathrm{cal} / \mathrm{mol}$

$\Delta H_{5}=\mathrm{KCl}(l)$ の生成熱 $=-100,164 \mathrm{cal} / \mathrm{mol}$

$\Delta H_{6}=\mathrm{NaIO}_{3}(s)$ の溶解熱 $=+4,040 \mathrm{cal} / \mathrm{mol}$

したがって $\mathrm{NaIO}_{3}(s)$ の生成熱 $\Delta H_{2}=-116,380 \mathrm{cal} /$ $\mathrm{mol}$ となる. ゆえに（1）式の反応熱を $Q \mathrm{cal} / \mathrm{mol}$ とす れば

$$
Q=-\Delta H=-\Delta H_{1}+\Delta H_{2}=-47,100 \mathrm{cal} / \mathrm{mol}
$$

(2) 式において $\Sigma n=3 / 2, \Sigma n I=3 / 2 \times 2.8=4.2$ 伸元に

$$
\log K=-47,100 / 4.574 T+3 / 2 \times 1.75 \log T+4.2
$$

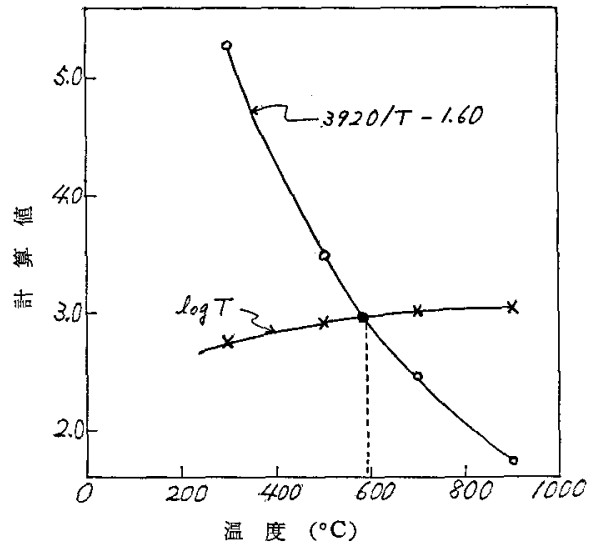

図 $4 \mathrm{NaIO}_{8}$ の分解温度

$$
=-10,300 / T+2.625 \log T+4.2
$$

(1) 式の分解温度すなわ酸素分压 $P_{\mathrm{O}_{2}}=1$ 気压に㐨 いて

$\log K=\log P_{\mathrm{O}_{2}}=0$

したがって分解温度は炊式を满足する $T$ から求めら 机る。

$10,300 / T=2.625 \log T+4.2$

または $\log T=3,920 / T-1.60$

図によってこの温度を求めると図 4 上り $590^{\circ} \mathrm{C}$ が得 られる.以上の計算は気相中の $P_{\mathrm{NaIO}_{3}}$ および $P_{\mathrm{NaI}}$ は 無視しうるちのとした。実際に NaI の蒸気圧は $700^{\circ} \mathrm{C}$ 以下にわいては，ほとんど問題にならないはど小さい。

実験結果によると， $500^{\circ} \mathrm{C}$ 付近より部分的分解がおと っている．てれはこの反志が発熱反応であり，熱的な不 均一によるものと思われ，実際の分解温度を示しておら ない.

てれに対してヨウ素発生の可能性について検討すると つぎのようになる，反応式としては次式が考光られる，

$$
\mathrm{NaIO}_{3}(s)=1 / 2 \mathrm{Na}_{2} \mathrm{O}_{2}(s)+1 / 2 \mathrm{I}_{2}+\mathrm{O}_{2}
$$

(2) 式化いて $\sum n=1+1 / 2=3 / 2$

$$
\Sigma n I=1 / 2 \times 3.9+2.8=4.75
$$

$\mathrm{Na}_{2} \mathrm{O}_{2}(s)$ の生成熱 $\Delta H_{7}=-119,200 \mathrm{cal} / \mathrm{mol}$

ゆえに反応熱 $Q=(-\Delta H)=-56,780 \mathrm{cal} / \mathrm{mol}$ したがって（2）式は

$\log K=-12,400 / T+2.625 \log T+4.75$

いま $\mathrm{Na}_{2} \mathrm{O}_{2}$ の分解温度 $460^{\circ} \mathrm{C}$ 以下の平衡定数を求 めると

$$
\begin{aligned}
& T=473^{\circ} \mathrm{K} \text { において } K=3.72+10^{-15} \\
& T=573^{\circ} \mathrm{K} \text { において } K=2.46 \times 10^{-10} \\
& T=733^{\circ} \mathrm{K} \text { において } K=2.40 \times 10^{-5}
\end{aligned}
$$

これによると $\mathrm{NaIO}_{3}(s)$ からヨウ素発生の可能性は 非常に少ないと考えられる．実際には少量のヨウ㪰ガス の発生を見たのは，微量金属など不純物による接触的分 解が考元られる.さらに炭素を混合した場合について同 
樣にして次式について平衡定数を求めると

$2 \mathrm{NaIO}_{3}(s)+\mathrm{C}(s)=2 \mathrm{NaI}(s)+\mathrm{CO}_{2}+2 \mathrm{O}_{2} \quad(4)$

$100^{\circ} \mathrm{C}$ において $K=2.46 \times 10^{21}$ となり爆発的反応が 行なわれることになる.実験結果にて得た $350^{\circ} \mathrm{C} は$ は らに検討の必要があるが，多量処理の場合危隃が予想さ れる。

以上の実験結果および考察からヨウ䒺酸ナトリウムか らヨウ化ナトリウムの回収方法として熱分解による場合 加熱温度 $600 \sim 650^{\circ} \mathrm{C}$ に扔いて十分な均一加熱のもとで ヨウ素損失は $1 \%$ 以下 $\left(\mathrm{NaIO}_{3}\right.$ 換算) 亿止めることが 可能である.

\section{4 結言}

ヨウ素酸ナトリウムからヨウ化ナトリウムを能率よく 回収する方法として熱分解法について検討を行ない，そ の反応過程を考察した結果はつぎのようである。

（1） $500^{\circ} \mathrm{C}$ 付近より部分的分解反応が行なわれ，
$600 \sim 650^{\circ} \mathrm{C}$ において短時間に溶融・分解し酸素 を效出してヨウ化物となる。

（2）熱力学的には分解温度 $590^{\circ} \mathrm{C}$ を得たが，発熱 反応による熱的不均一によるものと考元られる。

(3) 乙の際 1 2\% のヨウ素を発生する. 理論的に はヨウ素・酸素発生反応のおてる可能性はきわめ

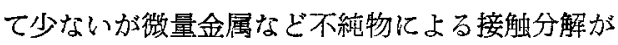
荐兑ら机る。

（4）熱分解法によって,ヨウ素損失 196 以下にて ウ化物を回収することができる。

終りにのぞみ終始ごべんたつを頂いた大阪大学工学部石野俊 夫教授に厚くお礼申し上げます。（昭 39-10-3 受理）

\section{文}

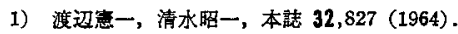

2) M. Berthelot, Compt. Rend. 84, 734 (1877).

3) C.F. Rammelsberg, Ann. 137, 305 (1868).

4) C.H. Cook, J. Chem. Soc. 65, 802 (1894).

\section{塩素酸ナトリウムとメタノールの反応}

\section{The Reaction of Sodium Chlorate and Methanol}

渡 辺 憲一*, 清 水昭 -**

Kenichi Watanabe, Shoichi Shimizu

\section{1 緒}

\section{曹}

塭素酸ナトリウムを還元して，二酸化㙁素をうる方法 として、 Schuber ${ }^{11}$ はメタノールが有効であると報告し ている。

また米国マチーソン社の特許)によればホルムアルデ ヒドがさらに効果的である旨記載されている。ての酸化 還元反心においては,メタノールが 3 段の酸化過程を経 過するととによって反虑の複雑なてとが予想されるが， この種の反応過程関して詳細な報告は見当たらない，

こてに二酸化塩素の純度および叹量に重点を置いて， この酸化還元反応の検討を行なった。

\section{2 実験方法}

反店器沬気密かきまぜ機付四ッロフラスコを用い，塩 莱酸ナトリウム水溶液を入れ，一定温度にて，ビューレ シトよりメタノールをできるだけ定速に注加した。なお 登些する二酸化塩素ガスを希釈のため別個に空気を導入 Uた。

とのようにして得られた約 10 vol％の二酸化塩素は

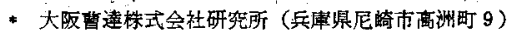

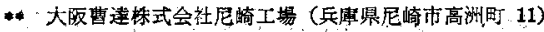

グラスウールを充てんしたトラップを経て吸収器中に尊 入し, 過酸化水素を含むカセイソーダ水溶液に吸収させ た.

この過酸化水素は適当に補給し，さらに念のために同 樣の第 2 吸収器を倩光て,アスピレーターによって败引 しながら二酸化塩素の完全吸収を図った。

\section{3 分析方 法}

発生ガスの総量を求めるための吸取器中における反応 は次式にしたがって，ほぼ定量的に行なわれると考元ら れる。

$\mathrm{Cl}_{2}+2 \mathrm{NaOH}+\mathrm{H}_{2} \mathrm{O}_{2}=2 \mathrm{NaCl}+2 \mathrm{H}_{2} \mathrm{O}+\mathrm{O}_{2}$

$2 \mathrm{ClO}_{2}+2 \mathrm{NaOH}+\mathrm{H}_{2} \mathrm{O}_{2}=2 \mathrm{NaClO}_{2}+2 \mathrm{H}_{2} \mathrm{O}+\mathrm{O}_{2}$

しかしての場合少量生成する塩素酸ナトリウムに対し て，次式にしたがって，ガス量の補正を行なった。

$3 \mathrm{NaClO}_{2}=\mathrm{NaCl}+2 \mathrm{NaClO}_{3}$

すなわ古吸收液中 $\mathrm{NaClO}_{2}=A$ モル, $\mathrm{NaCl}=B$ モル， $\mathrm{NaClO}_{3}=C$ モルとすれば，発生ガス量はそれぞれつぎ の上うにして求めた。

$$
\begin{aligned}
& \mathrm{ClO}_{2}=(A+3 / 2 C) \text { モル } \\
& \mathrm{Cl}_{2}=1 / 2(B-1 / 2 C) \text { モル }
\end{aligned}
$$

主成する亜塩素酸イオン，㙁素酸イオンおよび塩素】 